\title{
Finding the Right Way to Target EGFR in Glioblastomas; Lessons from Lung Adenocarcinomas
}

\author{
Ya Gao ${ }^{\mathbb{D}}$, Wies R. Vallentgoed and Pim J. French *(D) \\ Department of Neurology, Erasmus MC Cancer Institute; 3015 CD Rotterdam, The Netherlands; \\ y.gao@erasmusmc.nl (Y.G.); w.vallentgoed@erasmusmc.nl (W.R.V.) \\ * Correspondence: p.french@erasmusmc.nl; Tel.: +31-10-704-4333
}

Received: 9 November 2018; Accepted: 30 November 2018; Published: 4 December 2018

check for updates

\begin{abstract}
The EGFR gene is one of the most frequently mutated and/or amplified gene both in lung adenocarcinomas (LUAD) and in glioblastomas (GBMs). Although both tumor types depend on the mutation for growth, clinical benefit of EGFR tyrosine kinase inhibitors (TKIs) has only been observed in LUAD patients and, thus-far, not in GBM patients. Also in LUAD patients however, responses are restricted to specific EGFR mutations only and these 'TKI-sensitive' mutations hardly occur in GBMs. This argues for mutation-specific (as opposed to tumor-type specific) responses to EGFR-TKIs. We here discuss potential reasons for the differences in mutation spectrum and highlight recent evidence for specific functions of different EGFR mutations. These mutation-specific effects likely underlie the differential treatment response between LUAD and GBMs and provide new insights into how to target EGFR in GBM patients.
\end{abstract}

Keywords: EGFR; glioblastoma; glioma; pulmonary adenocarcinoma; lung cancer; erlotinib; gefitinib; lapatinib

\section{Introduction}

More than fifty years ago, Stanley Cohen reported on the isolation of a heat-stable protein from mouse salivary glands that was able to induce the eruption of incisors and separation of the eyelids [1]. Later studies showed that the eyelid separation was actually a consequence of enhanced keratinization and growth of the epidermis and, based on this function, the protein was coined epidermal growth factor (EGF) [2,3]. Around a decade later, the same group found evidence for a receptor for the growth factor on human fibroblasts and another decade later, the receptor was cloned and sequenced [4,5].

The EGF receptor (EGFR) gene encodes for a protein of 1210 amino acids which is built up of an extracellular ligand binding domain, a single transmembrane domain, a juxtamembrane region, an intracellular tyrosine kinase domain and a C-terminal regulatory domain. The extracellular region can be divided into four subdomains, domains I-IV, that contain two leucine rich regions (I and III, also known as L1 and L2) and two cysteine rich domains (II and IV, also known as CR1 and CR2). Proteins with a similar domain structure include ERBB2, ERBB3 and ERBB4 (which are also known as HER2-4), and are collectively known as the ERBB protein family, which are all members of the receptor tyrosine kinase superfamily.

In the absence of ligand, EGFR exists as a monomer (or as an inactive dimer) on the plasma membrane. When ligands are available, they bind to the extracellular leucine rich domains I and III, and this association results in the exposure of the cysteine rich domain II, which allows for receptor dimerization. The dimerization then induces phosphorylation of tyrosine residues on the C-terminal intracellular domain of the dimerization partner (trans-phosphorylation) [6]. Phosphorylation occurs on multiple sites: the intracellular domain contains twenty tyrosine residues, twelve of which can be phosphorylated following ligand binding [7]. This phosphorylation results in the recruitment of 
specific adaptor proteins and subsequent activation of signal transduction cascades. These cascades include the RAS-RAF-MEK-ERK, PI3kinase-AKT-mTOR, SRC, JNK, PLC- $\gamma$-PKC and STAT pathways and ultimately result in cellular proliferation, migration and survival $[8,9]$.

Although the EGF receptor (EGFR) was identified based on its affinity for EGF, later studies showed it can be also activated by six other, related- ligands: heparin-binding EGF-like growth factor (HB-EGF), amphiregulin, epiregulin, epigen, betacellulin and transforming growth factor-alpha (TGF- $\alpha$ ) [10]. EGF, TGF- $\alpha$, HB-EGF and betacellulin are the ligands that bind with high affinity to EGFR; amphiregulin, epiregulin and epigen bind with 10-100 fold less affinity. Each ligand can induce quantitative differences in responses, but can also elicit ligand-specific responses [10,11].

\section{EGFR Mutations in LUAD and Gliomas}

Cancer is caused by the accumulation of acquired genetic changes in oncogenes and tumor suppressor genes. The epidermal growth factor receptor (EGFR) gene is a key oncogene that is mutated in many tumors including lung adenocarcinomas (LUAD) and glioblastomas (GBM). In LUAD, around $90 \%$ of all EGFR mutations comprise of either short in-frame deletions in exon 19 (in particular around residues 747-750) or the L858R missense mutation in exon 21 [12,13]. Other, less common mutations in LUAD include G719X missense mutations ( 3\%) and in-frame insertions in exon 20 $(\sim 3 \%)$ [14]. All these mutations result in increased and continuous EGFR phosphorylation and activation $[15,16]$.

In GBMs, the initial driving event is thought to be high copy number amplification of the EGFR gene, present in tumor cells as double minutes (extrachromosomal circular DNA fragments) with levels ranging from $>5$ to more than 100 copies per cell [17]. These double minutes likely increase the copy number (and RNA expression) of the oncogene more effectively compared to chromosomal amplification. Double minutes are unevenly distributed across the two daughter cells during cell division which enhances tumor heterogeneity and plasticity [17]. Amplification of the EGFR gene is followed by the acquisition of a plethora of mutations that include intragenic deletions, point mutations and gene-fusions [18]. Multiple EGFR mutations may be present within the same tumor which also contributes to tumor heterogeneity [19]. The most common EGFR mutation in GBM is the in-frame deletion of exon 2-7, coined EGFRvIII and occurs in $~ 50 \%$ of all EGFR-amplified GBM cases. EGFRvIII has impaired ligand binding and is constitutively active, though its activity is only $~ 10 \%$ of endogenous EGFR signaling [20]. Missense mutations that are commonly found in GBM are often located on the extracellular domain and include A289X, G598X and R108K mutations. These mutations also result in a constitutively active protein and increase the tumorigenic potential of cells [19].

Both in lung cancer and in GBMs, EGFR mutations are driver mutations and the tumors remain dependent on this oncogene for growth [21-24]. Despite the similarities in activity, the most prominent mutations in LUAD, exon-19 deletions and L858R, have, to date, never been identified in GBMs and the most common mutation in GBMs, EGFRvIII, has never been identified in LUAD. This indicates that each tumor type has an almost (see below), unique mutation spectrum [14,20].

\section{Clinical Activity of EGFR-TKIs in LUAD, But Not GBM Patients}

It is well known that EGFR-TKIs provide remarkable survival benefit to patients with EGFR-mutated LUAD. These benefits were initially discovered by research on clinical trials that examined the efficacy of EGFR-TKIs in LUAD patients, in which antitumor activity and an increase in survival was observed in patients who failed on prior chemotherapy $[25,26]$ : translational research showed that the clinical responses were correlated to mutations in EGFR [27,28]. Landmark studies such as the IPASS study showed that gefitinib improved the 12 months progression free survival in advanced, previously untreated pulmonary adenocarcinoma patients, but only in those patients where activating mutations in the EGFR gene were identified. Similar improvements were observed in EGFR-mutated, metastatic non-small cell lung cancer patients [29,30]. A phase III study that included only EGFR-mutated lung cancer patients confirmed these observations [29]. 
Because of the clinical responses observed in EGFR-mutated LUAD patients, and because of the high frequency of EGFR mutations in GBMs, it was logical to test the clinical efficacy of EGFR-TKIs in GBM patients. Although several such trials have been conducted (Table 1), thus-far none of these demonstrated a clear clinical benefit of the inhibitors, despite inhibitors showing target inhibition on the various EGFR mutations in preclinical models [19]. For example, two studies conducted in primary gliomas showed no additional clinical benefit of adding gefitinib after radiotherapy [31,32]. Similar disappointing data were obtained in two studies on recurrent gliomas where single agent erlotinib did not improve the 6 months progression-free survival $[33,34]$.

Table 1. clinical trials of EGFR-TKIs in gliomas.

\begin{tabular}{|c|c|c|c|c|c|c|}
\hline Drug & Phase & Clinical Trial ID & Comparator & Histology & $n$ & Ref. \\
\hline $\mathrm{Erl}+\mathrm{TMZ} / \mathrm{RT}$ & $\mathrm{I} / \mathrm{II}$ & NCT00039494 & single arm & GBM & 97 & [35] \\
\hline $\mathrm{Erl}+\mathrm{Bev}$ & II & NCT00671970 & single arm & GBM, AG & 57 & [36] \\
\hline Erl + Soraf & II & NCT00445588 & single arm & rGBM & 56 & [37] \\
\hline $\mathrm{Erl}+\mathrm{Bev}+\mathrm{TMZ}$ & II & NCT00525525 & single arm & GBM, GSC & 74 & [38] \\
\hline $\mathrm{Erl}+\mathrm{TMZ}$ & II & NCT00187486 & single arm & GBM, GLS & 65 & [39] \\
\hline Erl & $\mathrm{I} / \mathrm{II}$ & NCT00301418 & single arm & GBM, AA & 11 & [40] \\
\hline $\mathrm{Erl}+$ Sirol & II & NCT00672243 & single arm & rGBM & 32 & [41] \\
\hline Erl + Sirol & $\mathrm{I} / \mathrm{II}$ & NCT00112736 & single arm & rGlioma & 69 & [42] \\
\hline Erl & II & NCT00250887 & $\mathrm{TMZ} / \mathrm{BCNU}$ & rGBM & 110 & [34] \\
\hline Gef & II & NCT00250887 & single arm & rGBM & 22 & [43] \\
\hline Gef + Cedir & II & NCT01310855 & Cedir & rGBM & 38 & [44] \\
\hline Gef & II & NCT00016991 & Single arm & rGBM & 57 & [45] \\
\hline Lap & I/II & NCT00099060 & single arm & rGBM & 17 & [46] \\
\hline Afa & $\mathrm{I} / \mathrm{II}$ & NCT00727506 & TMZ/afa, TMZ & rGBM & 119 & [47] \\
\hline Dac & II & NCT01520870 & single arm & rGBM & 49 & [48] \\
\hline Sun & II & NCT00923117 & Bev naïve/resistant & GBM & 72 & [49] \\
\hline
\end{tabular}

There are several possibilities why those trials failed to improve on their primary endpoint. First of all, the trials may not have included the right patient population. While this seems trivial, trials testing EGFR-TKIs selected patients based on histological criteria and did not select for EGFR-mutated tumors $[31,33,43,45,50]$. However, the frequency of EGFR amplification and mutations are sufficiently high in GBM patients (estimated to be $\sim 50 \%$ of all GBMs) to show some signal of efficacy. Moreover, translational research on the material from these trials also failed to show clinical improvement in the samples that had EGFR-mutations [31,34,51,52]. A second possibility for trial failure is that the concentration of drug does not reach sufficiently high concentrations in the tumor, for example by lack of penetration through the blood brain barrier. Indeed, intratumoral drug concentrations for erlotinib were much lower of that in plasma and erlotinib did not affect intratumoral EGFR signaling [33]. In contrast, a phase II trial in which the intratumoral levels of gefitinib was measured in 22 patients showed concentrations sufficiently high to inhibit the phosphorylation of EGFR [43].

A third option for therapy refractoriness of GBMs to EGFR-TKIs is that these tumors no longer depend on the oncogene for growth. However, biological experiments conducted in mice and using primary patient cell lines showed that these tumors do remain dependent on EGFR and therefore do not explain why GBMs do not respond to EGFR-TKIs [21,22]. It is possible that GBMs have an innate resistance to EGFR-TKIs, such as the upregulation (or coactivation) of PDGFRA and cMET [53]. Such an innate resistance has been identified in colon carcinomas where inhibition of one tyrosine 
kinase (BRAF) is bypassed by the activation of another (EGFR) [54]. Alternatively, perturbation of downstream pathways such as PTEN deletion may also confer resistance to EGFR TKIs [40]. It remains however to be determined if, and if so which-, changes (genetic or epi-genetic) underlie the therapy refractoriness of GBMs.

The dynamics of EGFR mutations can also play a role in treatment resistance of GBMs. Since EGFR is present as double minutes, cell division can result in the asymmetric distribution of EGFR copynumber and variants, and thus in rapid selection of potentially resistant clones [17]. An example of dynamics is the expression of EGFRvIII which can be restricted to certain regions of the tumor only and can change over time [55-57]. Our unpublished observations show that temporal dynamics is not restricted to EGFRvIII but also true for other EGFR mutations. If only one of those mutations is resistant to the TKI, the dynamics of double minutes likely results in a rapidly acquired resistance to EGFR-TKIs.

\section{Different Mutations Activate Different Pathways and May Explain Refractoriness to EGFR-TKIs}

On the functional level, several lines of evidence suggest that different mutations in EGFR activate unique signal transduction pathways. For example, EGFRvIII and EGFRwt have differential activation of the JNK, STAT and MAPK signaling pathways and induce the expression of a unique set of genes [58-62]. We have also demonstrated that EGFRwt, EGFRL858R and EGFRvIII each bind to a unique set of proteins and activate different molecular pathways [63]. If mutation-specific pathways active in GBMs are independent of EGFR phosphorylation, they explain why GBMs do not respond to EGFR-TKIs. For example, EGFR contains a functional nuclear localization signal and has been found present at high levels in the nucleus where it associates with the promoter of cell proliferation genes $[64,65]$. However, the nuclear accumulation is mutation dependent: mutations found in GBMs (e.g., EGFRvIII) accumulate in the nucleus whereas LUAD-specific mutations such as EGFR L858R do not [66-68]. Other studies have shown that the nuclear accumulation is independent of EGFR inhibitors [65,69]. It is therefore possible that activation of mutation-specific and TKI-independent pathways contribute to the lack of response to EGFR-TKIs. Which pathways are differentially activated and whether (co-) targeting these pathways will ultimately benefit GBM patients remains to be determined.

However, one argument against activation of mutation-specific pathway activation is the observation that some mutations have been found in both tumor types. Yes, the type of mutations vastly differs between LUAD and GBMs: exon 19 deletions or the EGFR L858R point mutations have never been found in GBMs and EGFRvIII is not present in $\operatorname{LUAD}[18,20]$. Sporadically however, exon 20 mutations, though rare in LUAD, have also been found in GBM patients [18]. Indeed, in a recent sequencing effort of $\sim 200$ GBM samples performed by our group, we identified two patients with mutations near identical to those found in LUAD (p.H773_V774insAH and p.H773dup) (Figure 1). Conversely, sporadic R108K, A289A/T and G598V mutations that are common in GBMs have been identified in LUAD (Figure 1) [70-72]. This overlap in mutational spectrum, though rare, may suggest that LUAD and GBMs are unlikely to activate mutation-specific pathways. However, since multiple mutations accumulate in the EGFR gene in GBMs, other activating mutations may confer potential mutation-specific effects. 


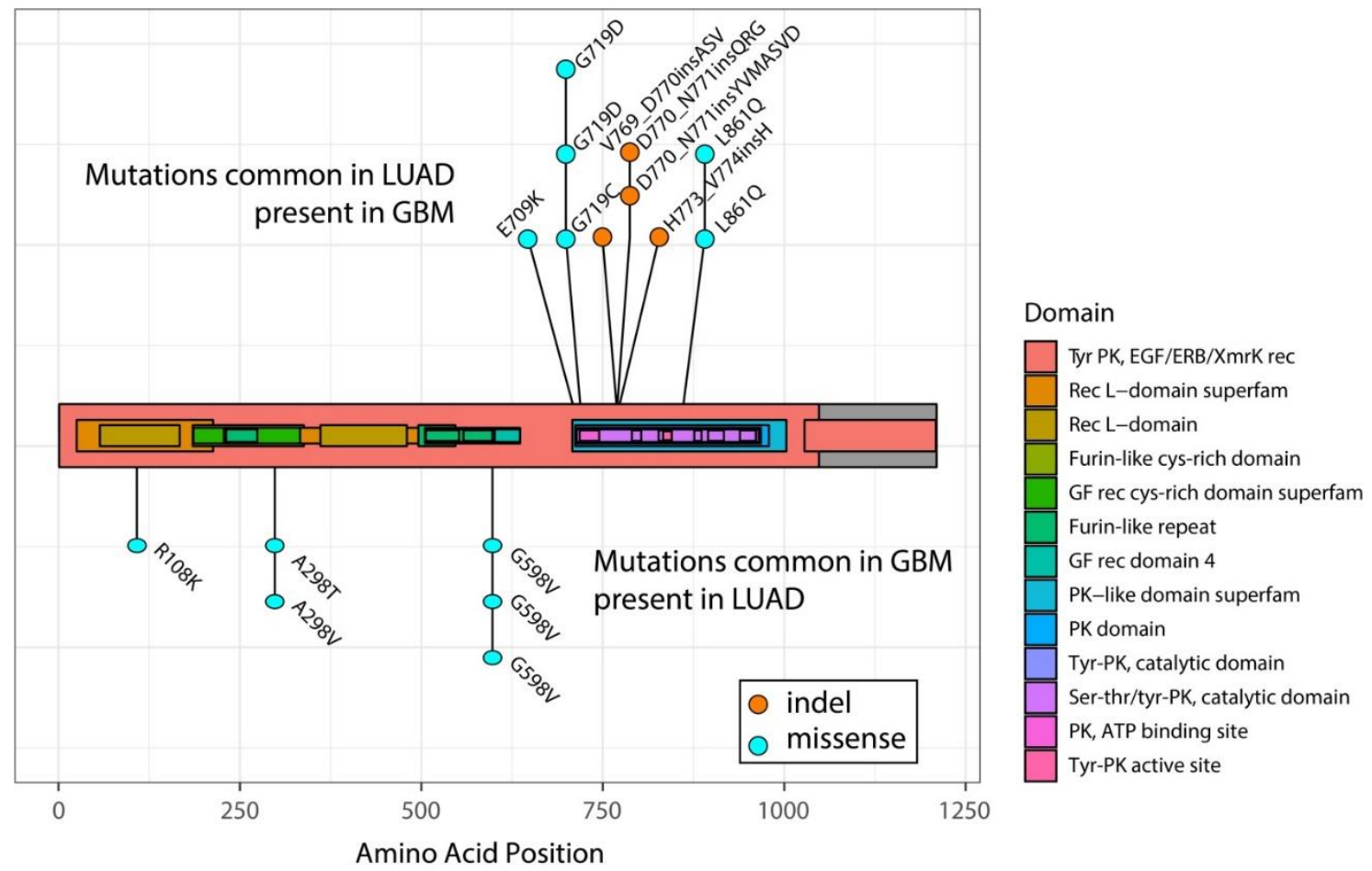

Figure 1. Mutations common to LUAD are sporadically identified in GBMs and vice versa. Each dot reflects a single sample identified with the specific mutation. Domains of EGFR are highlighted in color. PK: protein kinase; GF: growth factor; rec: receptor. The transmembrane is localized around amino acids $622-644$.

\section{Lessons from LUAD: Not all LUAD Respond to EGFR-TKIs and Not All TKIs are Effective in LUAD}

Mutations that show response to EGFR-TKIs in LUAD have sporadically been identified in other tumor types. In various tumors harboring 'classical' exon 19 deletions or the L858R point mutation, EGFR-TKIs have shown clinical responses [73-75]. Such responses have also been documented for the less common, but responsive, G719X mutations, also in different tumor types [76,77]. The fact that sensitive mutations in LUAD appear also sensitive to TKIs in other tumor types indicates that response to EGFR-TKIs is not specific to the type of tumor, but is specific for the mutation present. This can have important consequences for GBM patients, as sporadic G719X mutations have been identified (Figure 1) [72,78].

This mutation-specific response is also conversely observed in LUAD patients: while the most common mutations in LUAD are sensitive to EGFR-TKIs, LUAD patients harboring exon 20 mutations are largely insensitive $[79,80]$. This lack of responsiveness was also observed with these mutations in various preclinical model systems [81,82]. Although rare, they comprise of $\sim 3 \%$ of all EGFR mutations in LUAD and are considered to be activating mutations. Interestingly, and despite the lack of a clinical response, addition of TKIs does result in EGFR dephosphorylation in preclinical model systems [83,84]. The observation that not all EGFR-mutated LUAD respond to EGFR-TKIs indicate that response is limited to a defined set of mutations only.

Apart from the mutation-specificity of the response, there also is evidence for drug-specificity: although several EGFR-TKIs (erlotinib, gefitinib, afatinib, dacomitinib and osimertinib) have provided clinical benefit to EGFR-mutated LUAD patients, a phase II study on lapatinib did not show any signs of clinical activity [85]. This lack of clinical activity is surprising as lapatinib, similar to the other listed TKIs, is a highly potent inhibitor of EGFR phosphorylation. Erlotinib and gefitinib were the first to be developed and are both reversible inhibitors. Afatinib and dacomitinib are second generation irreversible inhibitors and osimertinib is a third generation inhibitor that also inhibits EGFR containing 
the T790M resistance mutation. Although all inhibitors inhibit EGFR phosphorylation, each drug has its own unique binding pocket, kinetics and properties (see e.g., [86]). Of note in this is that drugs like erlotinib associate with the active conformation while lapatinib traps the protein in an inactive conformation [87-89]. Perhaps this drug-specific conformational association underlies the marked difference in treatment response.

Nevertheless, the lack of clinical activity to lapatinib indicates that response to EGFR-TKIs is specific to the drug that was used. If so, response to inhibitors is a highly specific event, in which only specific mutations (exon 19 deletions, L858R and G719X missense mutations), and in the context of specific drugs only provide clinical benefit. The absence of either will result in clinical inactivity. Importantly, this would mean a shift in research paradigms from understanding why certain tumors do not respond to research into why only specific mutations do respond. Understanding why tumors respond will then lead to better design of novel targeted treatments.

\section{Conclusions}

Only specific mutations in EGFR respond to treatment, and this response seems independent of the type of tumor. Conversely, activating mutations with lack of clinical response to EGFR-TKIs, such as those found in GBMs, also do not respond to treatment in LUAD patients. Treatment response therefore is not tumor-type dependent, but mutation dependent. Moreover, only specific drugs seem to provide clinical benefit, despite showing similar target inhibition. Response to inhibitors therefore appears to be a highly specific event: only specific mutations in the context of specific drugs provide clinical benefit. The absence of either will result in clinical inactivity. The specificity of response warrants further investigation into its mechanisms as understanding why tumors respond will lead to better design of novel targeted treatments.

Author Contributions: Conceptualization: Y.G. and P.J.F.; Writing-Original Draft Preparation: P.J.F.; Writing-Review and Editing: Y.G., W.R.V. and P.J.F.; Funding Acquisition: P.J.F.

Funding: This work was funded by the Dutch Cancer Foundation, KWF kankerbestrijding, grant numbers 11125 and 11026. P.J.F. received grant support from AbbVie.

Conflicts of Interest: The authors declare no conflict of interest.

\section{References}

1. Cohen, S. Isolation of a mouse submaxillary gland protein accelerating incisor eruption and eyelid opening in the new-born animal. J. Biol. Chem. 1962, 237, 1555-1562. [PubMed]

2. Cohen, S.; Elliott, G.A. The stimulation of epidermal keratinization by a protein isolated from the submaxillary gland of the mouse. J. Investig. Dermatol. 1963, 40, 1-5. [CrossRef] [PubMed]

3. Cohen, S. The stimulation of epidermal proliferation by a specific protein (EGF). Dev. Biol. 1965, 12, $394-407$. [CrossRef]

4. Carpenter, G.; Lembach, K.J.; Morrison, M.M.; Cohen, S. Characterization of the binding of 125-I-labeled epidermal growth factor to human fibroblasts. J. Biol. Chem. 1975, 250, 4297-4304. [PubMed]

5. Ullrich, A.; Coussens, L.; Hayflick, J.S.; Dull, T.J.; Gray, A.; Tam, A.W.; Lee, J.; Yarden, Y.; Libermann, T.A.; Schlessinger, J.; et al. Human epidermal growth factor receptor cDNA sequence and aberrant expression of the amplified gene in A431 epidermoid carcinoma cells. Nature 1984, 309, 418-425. [CrossRef] [PubMed]

6. Ferguson, K.M. Structure-based view of epidermal growth factor receptor regulation. Annu. Rev. Biophys. 2008, 37, 353-373. [CrossRef] [PubMed]

7. Maruyama, I.N. Mechanisms of activation of receptor tyrosine kinases: Monomers or dimers. Cells 2014, 3, 304-330. [CrossRef] [PubMed]

8. Weinberg, R.A. The Biology of Cancer, 2nd ed.; Ww Norton \& Co.: New York, NY, USA, 2013.

9. Wee, P.; Wang, Z. Epidermal Growth Factor Receptor Cell Proliferation Signaling Pathways. Cancers (Basel) 2017, 9. [CrossRef]

10. Singh, B.; Carpenter, G.; Coffey, R.J. EGF receptor ligands: Recent advances. F1000Research 2016, 5. [CrossRef] 
11. Wilson, K.J.; Gilmore, J.L.; Foley, J.; Lemmon, M.A.; Riese, D.J., 2nd. Functional selectivity of EGF family peptide growth factors: Implications for cancer. Pharmacol. Ther. 2009, 122, 1-8. [CrossRef]

12. Campbell, J.D.; Alexandrov, A.; Kim, J.; Wala, J.; Berger, A.H.; Pedamallu, C.S.; Shukla, S.A.; Guo, G.; Brooks, A.N.; Murray, B.A.; et al. Distinct patterns of somatic genome alterations in lung adenocarcinomas and squamous cell carcinomas. Nat. Genet. 2016, 48, 607-616. [CrossRef] [PubMed]

13. Jordan, E.J.; Kim, H.R.; Arcila, M.E.; Barron, D.; Chakravarty, D.; Gao, J.; Chang, M.T.; Ni, A.; Kundra, R.; Jonsson, P.; et al. Prospective Comprehensive Molecular Characterization of Lung Adenocarcinomas for Efficient Patient Matching to Approved and Emerging Therapies. Cancer Discov. 2017, 7, 596-609. [CrossRef] [PubMed]

14. Sondka, Z.; Bamford, S.; Cole, C.G.; Ward, S.A.; Dunham, I.; Forbes, S.A. The COSMIC Cancer Gene Census: Describing genetic dysfunction across all human cancers. Nat. Rev. Cancer 2018. [CrossRef] [PubMed]

15. Gazdar, A.F. Activating and resistance mutations of EGFR in non-small-cell lung cancer: Role in clinical response to EGFR tyrosine kinase inhibitors. Oncogene 2009, 28 (Suppl. 1), S24-S31. [CrossRef] [PubMed]

16. Chen, Y.R.; Fu, Y.N.; Lin, C.H.; Yang, S.T.; Hu, S.F.; Chen, Y.T.; Tsai, S.F.; Huang, S.F. Distinctive activation patterns in constitutively active and gefitinib-sensitive EGFR mutants. Oncogene 2006, 25, 1205-1215. [CrossRef] [PubMed]

17. Turner, K.M.; Deshpande, V.; Beyter, D.; Koga, T.; Rusert, J.; Lee, C.; Li, B.; Arden, K.; Ren, B.; Nathanson, D.A.; et al. Extrachromosomal oncogene amplification drives tumour evolution and genetic heterogeneity. Nature 2017, 543, 122-125. [CrossRef]

18. Brennan, C.W.; Verhaak, R.G.; McKenna, A.; Campos, B.; Noushmehr, H.; Salama, S.R.; Zheng, S.; Chakravarty, D.; Sanborn, J.Z.; Berman, S.H.; et al. The somatic genomic landscape of glioblastoma. Cell 2013, 155, 462-477. [CrossRef]

19. Lee, J.C.; Vivanco, I.; Beroukhim, R.; Huang, J.H.; Feng, W.L.; DeBiasi, R.M.; Yoshimoto, K.; King, J.C.; Nghiemphu, P.; Yuza, Y.; et al. Epidermal growth factor receptor activation in glioblastoma through novel missense mutations in the extracellular domain. PLoS Med. 2006, 3, e485. [CrossRef]

20. Gan, H.K.; Cvrljevic, A.N.; Johns, T.G. The epidermal growth factor receptor variant III (EGFRvIII): Where wild things are altered. FEBS J. 2013, 280, 5350-5370. [CrossRef]

21. Klingler, S.; Guo, B.; Yao, J.; Yan, H.; Zhang, L.; Vaseva, A.V.; Chen, S.; Canoll, P.; Horner, J.W.; Wang, Y.A.; et al. Development of Resistance to EGFR-Targeted Therapy in Malignant Glioma Can Occur through EGFR-Dependent and -Independent Mechanisms. Cancer Res. 2015, 75, 2109-2119. [CrossRef]

22. Vivanco, I.; Robins, H.I.; Rohle, D.; Campos, C.; Grommes, C.; Nghiemphu, P.L.; Kubek, S.; Oldrini, B.; Chheda, M.G.; Yannuzzi, N.; et al. Differential sensitivity of glioma- versus lung cancer-specific EGFR mutations to EGFR kinase inhibitors. Cancer Discov. 2012, 2, 458-471. [CrossRef] [PubMed]

23. Politi, K.; Zakowski, M.F.; Fan, P.D.; Schonfeld, E.A.; Pao, W.; Varmus, H.E. Lung adenocarcinomas induced in mice by mutant EGF receptors found in human lung cancers respond to a tyrosine kinase inhibitor or to down-regulation of the receptors. Genes Dev. 2006, 20, 1496-1510. [CrossRef] [PubMed]

24. Ji, H.; Li, D.; Chen, L.; Shimamura, T.; Kobayashi, S.; McNamara, K.; Mahmood, U.; Mitchell, A.; Sun, Y.; Al-Hashem, R.; et al. The impact of human EGFR kinase domain mutations on lung tumorigenesis and in vivo sensitivity to EGFR-targeted therapies. Cancer Cell 2006, 9, 485-495. [CrossRef] [PubMed]

25. Shepherd, F.A.; Rodrigues Pereira, J.; Ciuleanu, T.; Tan, E.H.; Hirsh, V.; Thongprasert, S.; Campos, D.; Maoleekoonpiroj, S.; Smylie, M.; Martins, R.; et al. Erlotinib in previously treated non-small-cell lung cancer. N. Engl. J. Med. 2005, 353, 123-132. [CrossRef] [PubMed]

26. Fukuoka, M.; Yano, S.; Giaccone, G.; Tamura, T.; Nakagawa, K.; Douillard, J.Y.; Nishiwaki, Y.; Vansteenkiste, J.; Kudoh, S.; Rischin, D.; et al. Multi-institutional randomized phase II trial of gefitinib for previously treated patients with advanced non-small-cell lung cancer (The IDEAL 1 Trial) [corrected]. J. Clin. Oncol. 2003, 21, 2237-2246. [CrossRef] [PubMed]

27. Paez, J.G.; Janne, P.A.; Lee, J.C.; Tracy, S.; Greulich, H.; Gabriel, S.; Herman, P.; Kaye, F.J.; Lindeman, N.; Boggon, T.J.; et al. EGFR mutations in lung cancer: Correlation with clinical response to gefitinib therapy. Science 2004, 304, 1497-1500. [CrossRef]

28. Lynch, T.J.; Bell, D.W.; Sordella, R.; Gurubhagavatula, S.; Okimoto, R.A.; Brannigan, B.W.; Harris, P.L.; Haserlat, S.M.; Supko, J.G.; Haluska, F.G.; et al. Activating mutations in the epidermal growth factor receptor underlying responsiveness of non-small-cell lung cancer to gefitinib. N. Engl. J. Med. 2004, 350, 2129-2139. [CrossRef] 
29. Maemondo, M.; Inoue, A.; Kobayashi, K.; Sugawara, S.; Oizumi, S.; Isobe, H.; Gemma, A.; Harada, M.; Yoshizawa, H.; Kinoshita, I.; et al. Gefitinib or chemotherapy for non-small-cell lung cancer with mutated EGFR. N. Engl. J. Med. 2010, 362, 2380-2388. [CrossRef]

30. Mok, T.S.; Wu, Y.L.; Thongprasert, S.; Yang, C.H.; Chu, D.T.; Saijo, N.; Sunpaweravong, P.; Han, B.; Margono, B.; Ichinose, Y.; et al. Gefitinib or carboplatin-paclitaxel in pulmonary adenocarcinoma. N. Engl. J. Med. 2009, 361, 947-957. [CrossRef]

31. Uhm, J.H.; Ballman, K.V.; Wu, W.; Giannini, C.; Krauss, J.C.; Buckner, J.C.; James, C.D.; Scheithauer, B.W.; Behrens, R.J.; Flynn, P.J.; et al. Phase II evaluation of gefitinib in patients with newly diagnosed Grade 4 astrocytoma: Mayo/North Central Cancer Treatment Group Study N0074. Int. J. Radiat. Oncol. Biol. Phys. 2011, 80, 347-353. [CrossRef]

32. Chakravarti, A.; Wang, M.; Robins, H.I.; Lautenschlaeger, T.; Curran, W.J.; Brachman, D.G.; Schultz, C.J.; Choucair, A.; Dolled-Filhart, M.; Christiansen, J.; et al. RTOG 0211: A phase 1/2 study of radiation therapy with concurrent gefitinib for newly diagnosed glioblastoma patients. Int. J. Radiat. Oncol. Biol. Phys. 2013, 85, 1206-1211. [CrossRef]

33. Raizer, J.J.; Abrey, L.E.; Lassman, A.B.; Chang, S.M.; Lamborn, K.R.; Kuhn, J.G.; Yung, W.K.; Gilbert, M.R.; Aldape, K.A.; Wen, P.Y.; et al. A phase II trial of erlotinib in patients with recurrent malignant gliomas and nonprogressive glioblastoma multiforme postradiation therapy. Neuro. Oncol. 2010, 12, 95-103. [CrossRef]

34. van den Bent, M.J.; Brandes, A.A.; Rampling, R.; Kouwenhoven, M.C.; Kros, J.M.; Carpentier, A.F.; Clement, P.M.; Frenay, M.; Campone, M.; Baurain, J.F.; et al. Randomized phase II trial of erlotinib versus temozolomide or carmustine in recurrent glioblastoma: EORTC brain tumor group study 26034. J. Clin. Oncol. 2009, 27, 1268-1274. [CrossRef] [PubMed]

35. Brown, P.D.; Krishnan, S.; Sarkaria, J.N.; Wu, W.; Jaeckle, K.A.; Uhm, J.H.; Geoffroy, F.J.; Arusell, R.; Kitange, G.; Jenkins, R.B.; et al. Phase I/II trial of erlotinib and temozolomide with radiation therapy in the treatment of newly diagnosed glioblastoma multiforme: North Central Cancer Treatment Group Study N0177. J. Clin. Oncol. 2008, 26, 5603-5609. [CrossRef] [PubMed]

36. Sathornsumetee, S.; Desjardins, A.; Vredenburgh, J.J.; McLendon, R.E.; Marcello, J.; Herndon, J.E.; Mathe, A.; Hamilton, M.; Rich, J.N.; Norfleet, J.A.; et al. Phase II trial of bevacizumab and erlotinib in patients with recurrent malignant glioma. Neuro. Oncol. 2010, 12, 1300-1310. [CrossRef] [PubMed]

37. Peereboom, D.M.; Ahluwalia, M.S.; Ye, X.; Supko, J.G.; Hilderbrand, S.L.; Phuphanich, S.; Nabors, L.B.; Rosenfeld, M.R.; Mikkelsen, T.; Grossman, S.A.; et al. NABTT 0502: A phase II and pharmacokinetic study of erlotinib and sorafenib for patients with progressive or recurrent glioblastoma multiforme. Neuro. Oncol. 2013, 15, 490-496. [CrossRef]

38. Clarke, J.L.; Molinaro, A.M.; Phillips, J.J.; Butowski, N.A.; Chang, S.M.; Perry, A.; Costello, J.F.; DeSilva, A.A.; Rabbitt, J.E.; Prados, M.D. A single-institution phase II trial of radiation, temozolomide, erlotinib, and bevacizumab for initial treatment of glioblastoma. Neuro. Oncol. 2014, 16, 984-990. [CrossRef]

39. Prados, M.D.; Chang, S.M.; Butowski, N.; DeBoer, R.; Parvataneni, R.; Carliner, H.; Kabuubi, P.; Ayers-Ringler, J.; Rabbitt, J.; Page, M.; et al. Phase II study of erlotinib plus temozolomide during and after radiation therapy in patients with newly diagnosed glioblastoma multiforme or gliosarcoma. J. Clin. Oncol. 2009, 27, 579-584. [CrossRef]

40. Mellinghoff, I.K.; Wang, M.Y.; Vivanco, I.; Haas-Kogan, D.A.; Zhu, S.; Dia, E.Q.; Lu, K.V.; Yoshimoto, K.; Huang, J.H.; Chute, D.J.; et al. Molecular determinants of the response of glioblastomas to EGFR kinase inhibitors. N. Engl. J. Med. 2005, 353, 2012-2024. [CrossRef]

41. Reardon, D.A.; Desjardins, A.; Vredenburgh, J.J.; Gururangan, S.; Friedman, A.H.; Herndon, J.E., 2nd; Marcello, J.; Norfleet, J.A.; McLendon, R.E.; Sampson, J.H.; et al. Phase 2 trial of erlotinib plus sirolimus in adults with recurrent glioblastoma. J. Neurooncol. 2010, 96, 219-230. [CrossRef]

42. Wen, P.Y.; Chang, S.M.; Lamborn, K.R.; Kuhn, J.G.; Norden, A.D.; Cloughesy, T.F.; Robins, H.I.; Lieberman, F.S.; Gilbert, M.R.; Mehta, M.P.; et al. Phase I/II study of erlotinib and temsirolimus for patients with recurrent malignant gliomas: North American Brain Tumor Consortium trial 04-02. Neuro. Oncol. 2014, 16, 567-578. [CrossRef] [PubMed]

43. Hegi, M.E.; Diserens, A.C.; Bady, P.; Kamoshima, Y.; Kouwenhoven, M.C.; Delorenzi, M.; Lambiv, W.L.; Hamou, M.F.; Matter, M.S.; Koch, A.; et al. Pathway analysis of glioblastoma tissue after preoperative treatment with the EGFR tyrosine kinase inhibitor gefitinib-a phase II trial. Mol. Cancer Ther. 2011, 10, 1102-1112. [CrossRef] [PubMed] 
44. Brown, N.; McBain, C.; Nash, S.; Hopkins, K.; Sanghera, P.; Saran, F.; Phillips, M.; Dungey, F.; Clifton-Hadley, L.; Wanek, K.; et al. Multi-Center Randomized Phase II Study Comparing Cediranib plus Gefitinib with Cediranib plus Placebo in Subjects with Recurrent/Progressive Glioblastoma. PLoS ONE 2016, 11, e0156369. [CrossRef] [PubMed]

45. Rich, J.N.; Reardon, D.A.; Peery, T.; Dowell, J.M.; Quinn, J.A.; Penne, K.L.; Wikstrand, C.J.; Van Duyn, L.B.; Dancey, J.E.; McLendon, R.E.; et al. Phase II trial of gefitinib in recurrent glioblastoma. J. Clin. Oncol. 2004, 22, 133-142. [CrossRef] [PubMed]

46. Thiessen, B.; Stewart, C.; Tsao, M.; Kamel-Reid, S.; Schaiquevich, P.; Mason, W.; Easaw, J.; Belanger, K.; Forsyth, P.; McIntosh, L.; et al. A phase I/II trial of GW572016 (lapatinib) in recurrent glioblastoma multiforme: Clinical outcomes, pharmacokinetics and molecular correlation. Cancer Chemother. Pharmacol. 2010, 65, 353-361. [CrossRef] [PubMed]

47. Reardon, D.A.; Nabors, L.B.; Mason, W.P.; Perry, J.R.; Shapiro, W.; Kavan, P.; Mathieu, D.; Phuphanich, S.; Cseh, A.; Fu, Y.; et al. Phase I/randomized phase II study of afatinib, an irreversible ErbB family blocker, with or without protracted temozolomide in adults with recurrent glioblastoma. Neuro. Oncol. 2015, 17, 430-439. [CrossRef]

48. Sepulveda-Sanchez, J.M.; Vaz, M.A.; Balana, C.; Gil-Gil, M.; Reynes, G.; Gallego, O.; Martinez-Garcia, M.; Vicente, E.; Quindos, M.; Luque, R.; et al. Phase II trial of dacomitinib, a pan-human EGFR tyrosine kinase inhibitor, in recurrent glioblastoma patients with EGFR amplification. Neuro. Oncol. 2017, 19, 1522-1531. [CrossRef] [PubMed]

49. Kreisl, T.N.; Smith, P.; Sul, J.; Salgado, C.; Iwamoto, F.M.; Shih, J.H.; Fine, H.A. Continuous daily sunitinib for recurrent glioblastoma. J. Neurooncol. 2013, 111, 41-48. [CrossRef]

50. Reardon, D.A.; Quinn, J.A.; Vredenburgh, J.J.; Gururangan, S.; Friedman, A.H.; Desjardins, A.; Sathornsumetee, S.; Herndon, J.E., 2nd; Dowell, J.M.; McLendon, R.E.; et al. Phase 1 trial of gefitinib plus sirolimus in adults with recurrent malignant glioma. Clin. Cancer Res. 2006, 12, 860-868. [CrossRef]

51. Franceschi, E.; Cavallo, G.; Lonardi, S.; Magrini, E.; Tosoni, A.; Grosso, D.; Scopece, L.; Blatt, V.; Urbini, B.; Pession, A.; et al. Gefitinib in patients with progressive high-grade gliomas: A multicentre phase II study by Gruppo Italiano Cooperativo di Neuro-Oncologia (GICNO). Br. J. Cancer 2007, 96, 1047-1051. [CrossRef]

52. Yung, W.K.; Vredenburgh, J.J.; Cloughesy, T.F.; Nghiemphu, P.; Klencke, B.; Gilbert, M.R.; Reardon, D.A.; Prados, M.D. Safety and efficacy of erlotinib in first-relapse glioblastoma: A phase II open-label study. Neuro. Oncol. 2010, 12, 1061-1070. [CrossRef]

53. Stommel, J.M.; Kimmelman, A.C.; Ying, H.; Nabioullin, R.; Ponugoti, A.H.; Wiedemeyer, R.; Stegh, A.H.; Bradner, J.E.; Ligon, K.L.; Brennan, C.; et al. Coactivation of receptor tyrosine kinases affects the response of tumor cells to targeted therapies. Science 2007, 318, 287-290. [CrossRef] [PubMed]

54. Prahallad, A.; Sun, C.; Huang, S.; Di Nicolantonio, F.; Salazar, R.; Zecchin, D.; Beijersbergen, R.L.; Bardelli, A.; Bernards, R. Unresponsiveness of colon cancer to BRAF(V600E) inhibition through feedback activation of EGFR. Nature 2012, 483, 100-103. [CrossRef]

55. Del Vecchio, C.A.; Giacomini, C.P.; Vogel, H.; Jensen, K.C.; Florio, T.; Merlo, A.; Pollack, J.R.; Wong, A.J. EGFRvIII gene rearrangement is an early event in glioblastoma tumorigenesis and expression defines a hierarchy modulated by epigenetic mechanisms. Oncogene 2013, 32, 2670-2681. [CrossRef] [PubMed]

56. van den Bent, M.J.; Gao, Y.; Kerkhof, M.; Kros, J.M.; Gorlia, T.; van Zwieten, K.; Prince, J.; van Duinen, S.; Sillevis Smitt, P.A.; Taphoorn, M.; et al. Changes in the EGFR amplification and EGFRvIII expression between paired primary and recurrent glioblastomas. Neuro. Oncol. 2015, 17, 935-941. [CrossRef] [PubMed]

57. Nathanson, D.A.; Gini, B.; Mottahedeh, J.; Visnyei, K.; Koga, T.; Gomez, G.; Eskin, A.; Hwang, K.; Wang, J.; Masui, K.; et al. Targeted therapy resistance mediated by dynamic regulation of extrachromosomal mutant EGFR DNA. Science 2014, 343, 72-76. [CrossRef] [PubMed]

58. Antonyak, M.A.; Moscatello, D.K.; Wong, A.J. Constitutive activation of c-Jun N-terminal kinase by a mutant epidermal growth factor receptor. J. Biol. Chem. 1998, 273, 2817-2822. [CrossRef] [PubMed]

59. Chu, C.T.; Everiss, K.D.; Wikstrand, C.J.; Batra, S.K.; Kung, H.J.; Bigner, D.D. Receptor dimerization is not a factor in the signalling activity of a transforming variant epidermal growth factor receptor (EGFRvIII). Biochem. J. 1997, 324 Pt 3, 855-861. [CrossRef] [PubMed]

60. Chumbalkar, V.; Latha, K.; Hwang, Y.; Maywald, R.; Hawley, L.; Sawaya, R.; Diao, L.; Baggerly, K.; Cavenee, W.K.; Furnari, F.B.; et al. Analysis of phosphotyrosine signaling in glioblastoma identifies STAT5 as a novel downstream target of DeltaEGFR. J. Proteome Res. 2011, 10, 1343-1352. [CrossRef] 
61. Latha, K.; Li, M.; Chumbalkar, V.; Gururaj, A.; Hwang, Y.; Dakeng, S.; Sawaya, R.; Aldape, K.; Cavenee, W.K.; Bogler, O.; et al. Nuclear EGFRvIII-STAT5b complex contributes to glioblastoma cell survival by direct activation of the Bcl-XL promoter. Int. J. Cancer 2012. [CrossRef]

62. Pedersen, M.W.; Pedersen, N.; Damstrup, L.; Villingshoj, M.; Sonder, S.U.; Rieneck, K.; Bovin, L.F.; Spang-Thomsen, M.; Poulsen, H.S. Analysis of the epidermal growth factor receptor specific transcriptome: Effect of receptor expression level and an activating mutation. J. Cell. Biochem. 2005, 96, 412-427. [CrossRef] [PubMed]

63. Erdem-Eraslan, L.; Gao, Y.; Kloosterhof, N.K.; Atlasi, Y.; Demmers, J.; Sacchetti, A.; Kros, J.M.; Sillevis Smitt, P.; Aerts, J.; French, P.J. Mutation specific functions of EGFR result in a mutation-specific downstream pathway activation. Eur. J. Cancer 2015, 51, 893-903. [CrossRef]

64. Lin, S.Y.; Makino, K.; Xia, W.; Matin, A.; Wen, Y.; Kwong, K.Y.; Bourguignon, L.; Hung, M.C. Nuclear localization of EGF receptor and its potential new role as a transcription factor. Nat. Cell. Biol. 2001, 3, 802-808. [CrossRef] [PubMed]

65. Mikula, M.; Skrzypczak, M.; Goryca, K.; Paczkowska, K.; Ledwon, J.K.; Statkiewicz, M.; Kulecka, M.; Grzelak, M.; Dabrowska, M.; Kuklinska, U.; et al. Genome-wide co-localization of active EGFR and downstream ERK pathway kinases mirrors mitogen-inducible RNA polymerase 2 genomic occupancy. Nucleic. Acids Res. 2016, 44, 10150-10164. [CrossRef] [PubMed]

66. Liccardi, G.; Hartley, J.A.; Hochhauser, D. EGFR nuclear translocation modulates DNA repair following cisplatin and ionizing radiation treatment. Cancer Res. 2011, 71, 1103-1114. [CrossRef] [PubMed]

67. Lo, H.W.; Hsu, S.C.; Ali-Seyed, M.; Gunduz, M.; Xia, W.; Wei, Y.; Bartholomeusz, G.; Shih, J.Y.; Hung, M.C. Nuclear interaction of EGFR and STAT3 in the activation of the iNOS/NO pathway. Cancer Cell. 2005, 7, 575-589. [CrossRef] [PubMed]

68. Marti, U.; Ruchti, C.; Kampf, J.; Thomas, G.A.; Williams, E.D.; Peter, H.J.; Gerber, H.; Burgi, U. Nuclear localization of epidermal growth factor and epidermal growth factor receptors in human thyroid tissues. Thyroid 2001, 11, 137-145. [CrossRef] [PubMed]

69. Gururaj, A.E.; Gibson, L.; Panchabhai, S.; Bai, M.; Manyam, G.; Lu, Y.; Latha, K.; Rojas, M.L.; Hwang, Y.; Liang, S.; et al. Access to the nucleus and functional association with c-Myc is required for the full oncogenic potential of DeltaEGFR/EGFRvIII. J. Biol. Chem. 2013, 288, 3428-3438. [CrossRef] [PubMed]

70. Bollig-Fischer, A.; Chen, W.; Gadgeel, S.M.; Wenzlaff, A.S.; Cote, M.L.; Schwartz, A.G.; Bepler, G. Racial diversity of actionable mutations in non-small cell lung cancer. J. Thorac. Oncol. 2015, 10, 250-255. [CrossRef]

71. Seo, J.S.; Ju, Y.S.; Lee, W.C.; Shin, J.Y.; Lee, J.K.; Bleazard, T.; Lee, J.; Jung, Y.J.; Kim, J.O.; Shin, J.Y.; et al. The transcriptional landscape and mutational profile of lung adenocarcinoma. Genome Res. 2012, 22, 2109-2119. [CrossRef]

72. Zehir, A.; Benayed, R.; Shah, R.H.; Syed, A.; Middha, S.; Kim, H.R.; Srinivasan, P.; Gao, J.; Chakravarty, D.; Devlin, S.M.; et al. Mutational landscape of metastatic cancer revealed from prospective clinical sequencing of 10,000 patients. Nat. Med. 2017, 23, 703-713. [CrossRef] [PubMed]

73. Iyevleva, A.G.; Novik, A.V.; Moiseyenko, V.M.; Imyanitov, E.N. EGFR mutation in kidney carcinoma confers sensitivity to gefitinib treatment: A case report. Urol. Oncol. 2009, 27, 548-550. [CrossRef] [PubMed]

74. Masago, K.; Asato, R.; Fujita, S.; Hirano, S.; Tamura, Y.; Kanda, T.; Mio, T.; Katakami, N.; Mishima, M.; Ito, J. Epidermal growth factor receptor gene mutations in papillary thyroid carcinoma. Int. J. Cancer 2009, 124, 2744-2749. [CrossRef] [PubMed]

75. Ali, S.M.; Alpaugh, R.K.; Buell, J.K.; Stephens, P.J.; Yu, J.Q.; Wu, H.; Hiemstra, C.N.; Miller, V.A.; Lipson, D.; Palmer, G.A.; et al. Antitumor response of an ERBB2 amplified inflammatory breast carcinoma with EGFR mutation to the EGFR-TKI erlotinib. Clin. Breast Cancer 2014, 14, e14-e16. [CrossRef] [PubMed]

76. Voss, J.S.; Holtegaard, L.M.; Kerr, S.E.; Fritcher, E.G.; Roberts, L.R.; Gores, G.J.; Zhang, J.; Highsmith, W.E.; Halling, K.C.; Kipp, B.R. Molecular profiling of cholangiocarcinoma shows potential for targeted therapy treatment decisions. Hum. Pathol. 2013, 44, 1216-1222. [CrossRef]

77. Agatsuma, N.; Yasuda, Y.; Ozasa, H. Malignant Pleural Mesothelioma Harboring Both G719C and S768I Mutations of EGFR Successfully Treated with Afatinib. J. Thorac. Oncol. 2017, 12, e141-e143. [CrossRef]

78. Chi, A.S.; Batchelor, T.T.; Dias-Santagata, D.; Borger, D.; Stiles, C.D.; Wang, D.L.; Curry, W.T.; Wen, P.Y.; Ligon, K.L.; Ellisen, L.; et al. Prospective, high-throughput molecular profiling of human gliomas. J. Neurooncol. 2012, 110, 89-98. [CrossRef] [PubMed] 
79. Byeon, S.; Kim, Y.; Lim, S.W.; Cho, J.H.; Park, S.; Lee, J.; Sun, J.M.; Choi, Y.L.; Lee, S.H.; Ahn, J.S.; et al. Clinical Outcomes of EGFR Exon 20 Insertion Mutations in Advanced Non-small Cell Lung Cancer in Korea. Cancer Res. Treat. 2018. [CrossRef]

80. Yasuda, H.; Kobayashi, S.; Costa, D.B. EGFR exon 20 insertion mutations in non-small-cell lung cancer: Preclinical data and clinical implications. Lancet Oncol. 2012, 13, e23-e31. [CrossRef]

81. Hirano, T.; Yasuda, H.; Tani, T.; Hamamoto, J.; Oashi, A.; Ishioka, K.; Arai, D.; Nukaga, S.; Miyawaki, M.; Kawada, I.; et al. In vitro modeling to determine mutation specificity of EGFR tyrosine kinase inhibitors against clinically relevant EGFR mutants in non-small-cell lung cancer. Oncotarget 2015, 6, 38789-38803. [CrossRef]

82. Yang, M.; Xu, X.; Cai, J.; Ning, J.; Wery, J.P.; Li, Q.X. NSCLC harboring EGFR exon-20 insertions after the regulatory C-helix of kinase domain responds poorly to known EGFR inhibitors. Int. J. Cancer 2016, 139, 171-176. [CrossRef]

83. Ruan, Z.; Kannan, N. Altered conformational landscape and dimerization dependency underpins the activation of EGFR by alphaC-beta4 loop insertion mutations. Proc. Natl. Acad. Sci. USA 2018, 115, E8162-E8171. [CrossRef] [PubMed]

84. Hasako, S.; Terasaka, M.; Abe, N.; Uno, T.; Ohsawa, H.; Hashimoto, A.; Fujita, R.; Tanaka, K.; Okayama, T.; Wadhwa, R.; et al. TAS6417, A Novel EGFR Inhibitor Targeting Exon 20 Insertion Mutations. Mol. Cancer Ther. 2018, 17, 1648-1658. [CrossRef] [PubMed]

85. Ross, H.J.; Blumenschein, G.R., Jr.; Aisner, J.; Damjanov, N.; Dowlati, A.; Garst, J.; Rigas, J.R.; Smylie, M.; Hassani, H.; Allen, K.E.; et al. Randomized phase II multicenter trial of two schedules of lapatinib as first- or second-line monotherapy in patients with advanced or metastatic non-small cell lung cancer. Clin. Cancer Res. 2010, 16, 1938-1949. [CrossRef] [PubMed]

86. Jia, Y.; Yun, C.H.; Park, E.; Ercan, D.; Manuia, M.; Juarez, J.; Xu, C.; Rhee, K.; Chen, T.; Zhang, H.; et al. Overcoming EGFR(T790M) and EGFR(C797S) resistance with mutant-selective allosteric inhibitors. Nature 2016, 534, 129-132. [CrossRef]

87. Stamos, J.; Sliwkowski, M.X.; Eigenbrot, C. Structure of the epidermal growth factor receptor kinase domain alone and in complex with a 4-anilinoquinazoline inhibitor. J. Biol. Chem. 2002, 277, 46265-46272. [CrossRef]

88. Zhang, X.; Gureasko, J.; Shen, K.; Cole, P.A.; Kuriyan, J. An allosteric mechanism for activation of the kinase domain of epidermal growth factor receptor. Cell. 2006, 125, 1137-1149. [CrossRef]

89. Wood, E.R.; Truesdale, A.T.; McDonald, O.B.; Yuan, D.; Hassell, A.; Dickerson, S.H.; Ellis, B.; Pennisi, C.; Horne, E.; Lackey, K.; et al. A unique structure for epidermal growth factor receptor bound to GW572016 (Lapatinib): Relationships among protein conformation, inhibitor off-rate, and receptor activity in tumor cells. Cancer Res. 2004, 64, 6652-6659. [CrossRef] [PubMed]

(C) 2018 by the authors. Licensee MDPI, Basel, Switzerland. This article is an open access article distributed under the terms and conditions of the Creative Commons Attribution (CC BY) license (http://creativecommons.org/licenses/by/4.0/). 